IRA-International Journal of Education \& Multidisciplinary Studies

ISSN 2455-2526; Vol.08, Issue 01 (July 2017)

Pg. no. 44-52

Institute of Research Advances

http://research-advances.org/index.php/IJEMS

\title{
Re-'Writing' and Reconstructing History of Tripura through Image-Text-Culture Representation: An Analysis of Comicbook Senapati Ray Kachag
}

\author{
Dr. Archita Gupta \\ PG Teacher in the Directorate of School Education, Tripura, India.
}

Type of Review: Peer Reviewed.

DOI: http://dx.doi.org/10.21013/jems.v8.n1.p6

\section{How to cite this paper:}

Gupta, A. (2017). Re-'Writing' and Reconstructing History of Tripura through Image-Text-Culture Representation: An Analysis of Comicbook Senapati Ray Kachag. IRA International Journal of Education and Multidisciplinary Studies (ISSN 2455-2526), 8(1), 44-52. doi:http://dx.doi.org/10.21013/jems.v8.n1.p6

(C) Institute of Research Advances.

\section{(cc)) BY-NC}

This work is licensed under a Creative Commons Attribution-Non Commercial 4.0 International License subject to proper citation to the publication source of the work.

Disclaimer: The scholarly papers as reviewed and published by the Institute of Research Advances (IRA) are the views and opinions of their respective authors and are not the views or opinions of the IRA. The IRA disclaims of any harm or loss caused due to the published content to any party.

Institute of Research Advances is an institutional publisher member of Publishers Inter Linking Association Inc. (PILA-CrossRef), USA. The institute is an institutional signatory to the Budapest Open Access Initiative, Hungary advocating the open access of scientific and scholarly knowledge. The Institute is a registered content provider under Open Access Initiative Protocol for Metadata Harvesting (OAI-PMH).

The journal is indexed \& included in WorldCat Discovery Service (USA), CrossRef Metadata Search (USA), WorldCat (USA), OCLC (USA), Open J-Gate (India), EZB (Germany) Scilit (Switzerland), Airiti (China), Bielefeld Academic Search Engine (BASE) of Bielefeld University, Germany, PKP Index of Simon Fraser University, Canada. 


\begin{abstract}
This paper attempts to analyze comic book Senapati Ray Kachag based on the fifteenth century chivalrous Reang General of King Dhanyamanikya, as a comprehensive document recording Tripura's historical and geographical facts, history of art and culture through image and text. It presents a non-conventional and non-canonical history of Tripura. In the course of this paper attempts will also be made to explore the populist appeal of visual texts evidenced by the existing academic pedagogy of comprehending History through story boards. In comic book mould the historical legend of Tripura, Ray Kachag and his story find an alternative expression using myth, folk-lore, folk life and culture as its ingredients and reconstructs history concerning oral historical traces defying monolithic 'writing'. The inclusion of Jamichalang, a folk hero of Tripura is interesting as he eludes and deludes any historical traces. He is a historical as he denies age and time by resisting the prime determiner of canonical and conventional historical documentation viz. chronology. This paper explores this visual text as an interdisciplinary field of study linking history, culture and literature expanding the frontier of knowledge in the discipline of history. History is always accompanied with some obscurity and half-visibility, and this obscurity in fact, facilitates the canonical history formation that involves the politics of inclusion or exclusion. . Adapting the comic book medium, the writer-illustrator of Senapati Ray Kachag Alak Dasgupta presents a blending of fact and fiction, humour and history. The list of books in acknowledgement section is documented, conventional and canonical history written more or less from the perspective of royalty of Tripura. To consider Senapati Ray Kachag a conventional history or legend would be erroneous as no attempt has been made to situate him in such way so far. This paper thus aims to enforce the idea of folk culture and life of Tripura forming a distinct thematic perspective, reconstructing history tracing the presence of a culture integral to historical process but absent in conventional and canonical history.
\end{abstract}

The difficulty associated with the concept of time and history writing is that although it incorporates change as movement from one steady-state to another, it cannot account for the process that motivates that change of time within the same cultural space. The temporal and spatial change remains obscure and therefore any attempt to 'write' the past time or history is a re-writing. The canonical writing of history of any cultural space is monolithic. Time is the accumulation of social practices layered in cultural space. Thus the set of practices, habits, customs and their expression in folk literature or counter -canonical practices accentuate the re-writing of history in various cultural 'texts' ('text' to be comprehended in post- modern sense) Such texts often blur the boundary of fact and fiction but attempt to relocate the gaps and absences through these 'social and cultural scripts' avoiding any authoritative stance .Senapati Ray Kachag attempts to present a non-conventional and non-canonical history of Tripura. It can be read as a comprehensive document concerning Tripura's history and geographical facts, history of art and culture in a fictionalized attempt. The blending of fact and fiction is given the term 'faction' and it can be satisfactorily associated with Senapati Ray Kachag. Oliver Conolly and Bashar Haydan in their abstract to the paper "The Case Against Faction" talk about the difficulty in communication in such texts:

"Faction" is a hybrid genre, aiming at the factual accuracy of journalism on the one hand and the literary form of the novel on the other. There is a fundamental tension however between two aims, given the constraints which factual accuracy places on the characterization, plot and thematic exploration characteristics of the novel. Further "faction" cannot be defended on the grounds that factual accuracy is a literary value in faction. Finally some aspects of faction such as the inability to refer to sources or provide an analytical framework for a narrative hinder rather than facilitate the communication of facts (Conolly, Oliver and Bashar Haydan. Abstract).

Senapati Ray Kachag, can avoid such problems by first being a comic strip meant for children to let them know about Ray Kachag and second, by being a story based on historical facts. History is always accompanied with some obscurity and half-visibility, and this obscurity in fact, facilitates the canonical history formation that involves the politics of inclusion or exclusion. Thus historical facts or pseudo-historical facts render the comic strip open ended leaving much scope for serious readers. Comic strip in the mould of faction evokes many issues that lead to a noncanonical history formation both in form and content. The imagination associated with fiction cannot be completely 
expressed in faction because of constrains of 'reality' since it is an attempt either to 'faction'-alize fiction or fictionalize fact. History is not written, actually it is re-written, and therefore comic strip based on history can be taken as an instance of translation of facts(?) to fiction and can be analyzed taking into consideration translational relations. Adapting the comic book medium, the writer -illustrator of Senapati Ray Kachag Alak Dasgupta presents a blending of fact and fiction, humour and history. The list of books in acknowledgement section is documented, conventional and canonical history written more or less from the perspective of royalty of Tripura. But 'history of Ray Kachag, the chivalrous hero of fifteenth century Tripura' (Dasgupta, back cover of the book; trans. mine) is non-conventional both in its adaptation of theme and medium and its personages. It is to be remembered here that it is practically impossible ever to reconstruct the 'actuality' of the past as all reconstructions are provisional and depended on multiple interpretations since facts no longer speak for themselves. The epistemological notions of the positivists are being challenged on the ground that history is a literary artifact and that all historical sources are intertextual.

Mitchell Foucault (Foucault, 78) and Jacques Derrida (Derrida, 102) questioned the links between truth and the power system which shapes and determines it. They questioned the indefinite and multiplex relationship between the signifier and the signified, or in other words the nebulous quality of language. Language itself shapes and predetermines reality. Thus everything is a linguistic and textual construction. From this perspective it can be said that the written always enjoys a privilege in the literary and cultural sphere over the oral. Orality needs to be documented and thereby structured to be heard. This construction implies multiple connotation involving politics, dominance and power equation. This debate was taken up by Hayden White who regarded all history as verbal fiction that is partly invented. According to him, history is the persuasive exposition of point of view through the use of language(vi). This makes it possible for us to say that historical truth is not inherent in the evidence of events and that history is a constructed narrative. This construction of 'truth' is so 'real' that foundational status has been conferred upon it. The past comes before us through various stories which we interpret and can never break out of. It can be said that history is nothing but historiography, a matrix of reading practices that engage dialectically with existing texts representing an assortment of culturally constructed forms of knowledge, beliefs, codes and customs. Such writing is coloured by the discourse of somebody else. The following discussion on the comic strip Senapati Ray Kachag has been structured based on these theoretical postulations that are interdisciplinary in nature. The story (non-conventional and non canonical history) of Ray Kachag is a statement of neglect and exclusion. The folk life and folk culture of Tripura have not been included in details in any one of the constructs of documented written history.

The books collected so far documents only the story of kings. The discussion on real life patterns of the mass (the subjects who were generally of the ethnic tribal stock at that time in Tripura) is absent. The lifestyle of different tribes, their economic and cultural problems were not included. It is not possible to decipher clearly the aspects of mass consciousness until the opinion of the then masses is known. Rajmala or books of this type are based on the history and perspective of the royalty. There is mention of devotion to royalty and severe punishment for disobedience. But there is no mention as to why such devotion is not permanent in the mind of the devotee and periodically erupts in the form of revolution (Dey 80-81; trans mine).

The uniqueness of Senapati Ray Kachag lies in the fact that it includes history and culture of Tripura and projects them in a comic mould in such a manner that historical and pseudo-historical facts appear convincing and penetrative. The historical legend of Tripura, Ray Kachag and his story finds an alternative expression using myth, folk-lore, folk life and culture as its ingredients. It is an attempt to reconstruct history from the perspective of folk culture and folk life. To consider Senapati Ray Kachag a conventional history or legend would be erroneous as no attempt has been made to situate him in such way so far. It is a deviation in this respect from dry, historical fact that presents only one facet of an era. The text uses etiologic tales to render certain uniqueness to the medium it employs. Etiologic tales are close to myths. They are used to refer to the description or assignment of causes. Accordingly, an etiologic tale explains the origin of a custom, stock of affairs, or natural feature in the human or divine world. There is an abundance of such tales in Senapati Ray Kachag - the origin of 'Garia' ${ }^{1}$ dance, the sculpture of 'Debatamura', the reference to Komodo dragon of Indonesia ${ }^{3}$ etc. Such tales actually amount to myth and can be termed also as pseudo -historical. Here it is important to draw a line of demarcation between history and myth as the latter represents alternate ways of looking at the past. History requires the presence of writing in order so that concerning versions of the past may be recorded and evaluated. On the other hand, myth as a space excludes writing and literacy. Myth is cited when a situation in the present needs to be understood as a consequence of the past. Myth 
constitutes a major part of a culture and historians also rely sometimes on myth. History should be understood as accompanying everything surrounding it and Senapati Ray Kachag attempts to do the same. It is a re-rendering of record and attempts to create a sense of contemporaneity connecting two different time frames-past (the era of Ray Kachag i.e. $15^{\text {th }}$ century Tripura) and the present in which the book has been published. The text and the reader belong to present time. In creating the sense of contemporaneity it employs some aspects both in technique and content. Use of 'diya'or 'pradip', as comic strip iconography instead of 'bulb' as a symbolic representation of the origin of idea leads the readers back to the past (Dasgupta 11;48). The reference to the victory over Husen Shah and the placement of the Kaman (canon) in today's Kaman Chowmuhani, Agartala (Dasgupta 56) is also such an attempt with respect to the theme and content.

Senapati Ray Kachag places a 'peripheral' character (peripheral in viewing history from Royalty perspective) Ray Kachag a centrality of position since it is on him that the fate of the kingdom depends. Senapati Ray Kachag conforms to the children's literature genre in its inclusion of illustrations, as well as the style of illustration etc which lacks seriousness and is populist in appeal. But at the same time it also includes historical documents, geographic diagrams etal in its attempt to authenticate historical fact thus creating an alternate historiography both in content and technique. The illustrations are one- line drawings, humorous and nonserious conforming to children's literature format. But at the same time it reinforces the ethnic tribal culture specific codes through the illustrations. The signs/pictorial codes are used to indicate places even such as 'Rangamatia' ${ }^{5}$ where it has to be made comprehensive in one single frame as well as the illustration of 'Mata Tripureswari' temple (27) .The illustrations of musical instruments such as dhol (39), the dance movement and the circular pattern of dance (Figure 3.17) (26), the 'Vaishnavas' ${ }^{6}$ and their 'namgan' 7 (39) effectively visualize and disseminate the local cultural space. The obscurity of folk life due to a lack of attempt to bring them to light is countered in Senapati Ray Kachag. Use of culture-specific terms and efforts at retaining their actual meaning by the use of footnotes even in mainstream Bengali language substantiate this. Such examples include (the footnotes are given in bracket in translated form):' selam bari' (special military court, Dasgupta 18), 'rengpui' (the 'Kukis' called the king of Tripura 'Rengpui'. Dasgupta, 19), 'rambu' (present Kaksbazaar, Dasgupta 20), 'hasam bhojan' (the annual feast of the soldiers, Dasgupta 40), 'pathian'(the great god whom the Kukis worshipped, Dasgupta 25),'Tilak' (the cover of dry bottle gourd used as waterpot, Dasgupta 44) 'chakhui' (a delicious item made with 'khar' or cooking soda). In tribal community hierarchy, Tripuri community posits in the centre occupying the throne. The fact that an important figure of history has not yet got much attention calls for investigating the power equation involved in conventional canonical history writing. One major reason for this exclusion .may be that canonical history is centered on royalty where the dominant position belonged to members of Tripuri community who are still regarded as kshatriya. The kings of Tripura patronized the Bengali community and Bengali language more than their own tribes. Radhakishore Manikya Bahadur wrote to his minister Ramanimohan Chattopadhyay,

It is a matter of pride for a Bengali Hindu state that various attempt has been made for the use of Bengali language in royal official activities and for the development of the language. Specially I love Bengali language more than my life and consider it my prime duty to look into the development of the language...(qtd in Dey 168. trans and italics mine).

Ranjit Dey wrote:

Among the tribes of Tripura, Reang is one of the major groups. According to some researchers there is a tone of revolution even in the name Reang. In a well known legend it is said that they lived in the Mayathalang village of Bangladesh and had a different king. Perhaps they were governed by the king of Tripura. King Tripur was oppressive by nature. In Rajmala, it is said that he was more obsessed with his own luxury than his responsibility towards his subject. When king Tripur's attendants came to the leader of the group for collecting Royal Tax, their rebellious attitude was revealed. Perhaps the leader said 'aa ri ang' or 'riya ang' (I' will not give) that is I will not give the royal tax (Dey 80. Trans. mine).

The comic strip on Ray Kachag, therefore is a reconstruction of history concerning oral historical traces in the form of folktales, representation of ethnic life and culture. It is an indirect indictment to the construction of a multilingual, multicultural state hinting the inclusion vis-à-vis exclusion. The linking of documented history in the narrative is a device to create a fictional credibility in the narration. Senapati Ray Kachag is the translation of a folk narrative into 
mainstream Bengali language, the target language. Two major elements that are being translated are -language and form. It is an attempt to gain a larger space in the literary culture dominated by mainstream Bengali, but the comic genre because of its illustration resists folk or tribal culture to be translated and lost in the translation process. The text both in technique and content provide a certain affinity to historical/ pseudo-historical factuality. The technique used to refer to these historical facts is the pictorial code, thus generating a sense of both the past and at the same time also facilitating historical documentation. The noticeable thing is that it is different from a royal decree written for the purpose of communicating a royal message as used in the narrative (p14). A few of such instances are given below:

1. 'Baro Bidrohi Parba'- ('The Episode of Twelve Rebels', trans mine):The story of kachag's victory over the soldiers of Nawaab Allauddin Abul Mozafur Husen Shah. The following texts are inscribed as historical documents:

Itihas bale ora keo nistar paini, which translated to English would be: history says none of them were spared (Dasgupta 18, trans mine).

2. Senapati Ray Kachag ebong Gour bahini (General Ray Kachag and The army of Gour, trans mine.) : an imaginary incident showing two soldiers conversing on the induction of 'Aswarohi bahini' in Tripuri sena (cavalry regiment in Tripura army). One humorously concludes that when the other would retire, his post will be replaced by that of 'aswarohi bahini' hinting that it would take a long time (18).

The next panel that includes only an image of a paper resembling historical document writes:

It will be learned if we read history that the anonymous soldier was a foreseer because, much later after this incident, in 1540 king Bijoy Manikya started aswarohi bahini i.e. cavalry regiment in Tripura army (18, trans mine).

3. Senapati Ray Kachag ebong Gour Bahini(General Ray Kachag and The army of Gour, trans mine.): humour arises from the un-soldier like attitude of the two soldiers in Husen Shah 's army and their fondness for namgan . The background is that of Bhakti Movement. The same pictorial code refers:

Indeed a few days later, two brothers Dabir Khas and Sakir Mallik resigned their job and adopted Vaishnavism (and soon became the pioneering Vaishnab scholars Pandit Sreesanatan and Srirup Goswami. But it is another story (40, trans. mine).

4. Senapati Ray Kachag ebong Gour Bahini (General Ray Kachag and the army of Gour, trans. mine.): referring to the important speech by Dhanyamanikya in the hasam bhojan/annual feast on the bank of Kamalasagar.(40). $T$ he series also includes the story of the placement of Goddess Tripureswari in Rangamatia. The goddess appears in the dream of Dhanyamaanikya and orders him to bring her from' Chatatal' or 'Chattagram,8 (35).

5. Husen Shah er Kaman(The canon of Husen Shah, trans mine): the construction of Turka Dighi ${ }^{9}$ - After the pathetic death of Goursena (army of the kingdom of Gour) by drinking poisonous water of the River Gomati. After this tragic incident a lake was dug under order by Hantian Khan within only six hours. This lake later became famous as 'Turka Dighi'.(44, trans mine)

6. Husen Shah er Kaman: (The canon of Husen Shah, trans mine): reference to a soldier-artist Chabidas who accompanied Tripuri soldiers in the battle and humour associated with it- The readers have now known why a syncretic mode ('misraritir prabhab' in Bengali) can be observed in the sculpture of the deities of Debatamura'.(43, trans mine)

7. Swet hasti: referring to the emergence of Garia dance. It is mentioned in the strip that after defeating the Kukis $^{10}$ the soldiers took rest in many places, enjoyed by dancing and singing and the villagers also joined them. The narrative says- It is said that thus the tradition of Garia dance began (26, Trans. mine).

The writer-illustrator here does not take an authoritative stance as it is not certain. According to the Debbarma community the soldiers set off for the battle on the plain land after worshipping the Garia god. They won the battle although a long period was spent in it. They celebrate a festival after the end of the battle (Dey 97). If viewed from this perspective the narrative in the text coincides with history. The emergence of Bengali as prime language is also associated with the dance. Perhaps the soldiers of Tripuri army stayed for a long time in touch with the Bengali community while battling. This has influenced the language as well. Almost all the lyrics used in the magan ${ }^{31}$ are in Bengali.

Husen Shah er Kaman(The canon of Husen Shah, trans mine): reference to Kachag's reward by the King and the placement of the Kaman (meaning canon) in the present Kaman Chowmuhani area of Agartala. As the most 
chivalrous hero of the battle, Ray Kachag was conferred with the highest honour of the country such as many nontaxable (niskar) plots of land, ornaments, dresses, astrasastra (arms and weapons) and a unique elephant. Then only the king and his very close associates were allowed to use elephants (56 trans mine). And as far as the Kaman (canon) is concerned; friends and readers : The royal Kaman of the king of Gour Husen Shah is carefully preserved in the centre of the present capital of Agartala, Kaman Chowmuhani as a symbol of victory in the memorable battle.(56, trans mine)

The geographical details are given in the form of diagrams that function in the narrative as 'naksa'(meaning design) used in battle. The geographical details give the world of comic a sense of authenticity. It is very much different from the make-belief world of comics. Its aim is to contextualize a 'local' space in its linguistic and pictorial codes. Such instances are;

A map is included in the first panel of page 43 following the narrative: A terrible ('sanghatik' in Bengali) battle. Tripura lost many places. The following map will indicate the movement of the battle (43, trans mine)

The comic strip Senapati Ray Kachag consists of five stories nucleating around the chivalry of Ray Kachag as general and his utmost effort to save the kingdom of Tripura- the first is about Kachag's emergence as the leader of the protectors of his own village and his rise to the post of General in the army of King Dhanyamanikya. The story includes the torture and attacks of Kuki community on the Reangs and the conspiracy riddled kingdom. The background to the story says that it was the period of 1490 when king Dhanyamanikya ascended the throne but the real power was in the hands of arrogant, cunning and conspirating generals. The recovery from such a state was possible only for Ray Kachag, the general whom the king Dhanyamanikya could totally rely upon. The narrative /plot of the comic strip interconnects the vital part of Kachag's popularity as chivalrous hero of his village and his ascent to the post of general. The linguistic and the cultural code of the comic strip format enable the contextualization of a local space. The attempt at voicing or lending audibility to the story of a chivalrous hero of the fifteenth century in the history of Tripura which "is still unheard in Bengali literature" (as written in the back cover of the text) finds holistic expression in the comic book format because of its illustrative quality. It restricts a local space and local tribal culture from being lost in the process of registering it in a language which does not belong to that community. The pattern of life of the different tribes is here embedded in the image along with the linguistic message. The topography, dress, custom, manners etc are registered in the pictorial code. The attempt of the writerillustrator to retain the culture specific terms and their meaning such as rengpui, parthien, riya ,chakhui etc by the use of footnotes in the relay text complement the image and make the source culture more comprehensive for the readers. The linguistic and pictorial codes in their combined form creates a sense of the 'local' as against the 'national' or 'global' and more importantly against the cultural and linguistic domination of the so called mainstream. The writer here acts actually as a translator (inter-semiotic translation to be precise in the sense that the ST consists of oral traces in the form of folktales, myths, legends, non-conventional and non-canonical history in ethnic languages of Tripura such as Kokborok, Reang etal., whereas the TT is the comic strip in Bengali) in depicting a story of a tribal source culture in the mainstream Bengali language and literature. The comic strip genre and the appreciable attempt of the writer/ illustrator to retain tribal culture specificity (instead of being a part of mainstream Bengali) resists the source culture from being translated, transformed and thus lost in the target text (TT).

As pointed out earlier the comic strip on Ray Kachag is the result of long eight to ten years research on the history of Tripura as claimed by the publishing house Bhasa (Backcover of the book). The incorporation of historical facts in the narrative or the inclusion of narrative fiction in history is an attempt to acquaint the readers with this legend 'excluded' from grand canonical history such as the Rajmala. The narrative and history conform to each other in the depiction of the Kuki community as riotous and arrogant (Dey 116). The depiction of the Reangs and the Kukis exemplifies the binary of the domestic and the wild. The dress and behavior project the former as 'barbaric' in comparison to the more 'civilized' Reangs. It has correspondence to documented historical evidence by Ranjit Dey who writes that except those that cause death or extreme illness, they (the Kukis) ate all kinds of food (116) and that among the tribes of Tripura the Kukis are the most indomitable and warlike ('durdanta o samarpriya' in Bengali). At the beginning of $16^{\text {th }}$ century, the King Dhanyamanikya gained victory over the Thanangsi castle of Kuki state. From that time onwards the Kukis created constant trouble and remained an indigestable item in the stomach of Tripura kingdom (Dey 82, trans. mine). 
The Thanangsi castle of Kuki kingdom finds reference in 'Swet Hasti Parba'(The Episode of White Elephant, trans.mine). It is referred here as Thanasigarh. The living pattern of the Kuki in the highland as shown in the text has historical verity. Their habitat in the highland created much trouble for the army of Tripura. If closely examined the story in the series reflects the domination of royalty over the tribes. But ironically this domination and hierarchy remains hidden under the chivalry of Ray Kachag. There is reference in the story that the Kuki community gave the King elephant tusk, bamboo products and elephants as gift. The narrative runs thus: the soldiers of Kuki kingdom captured a white elephant in their area of Thanasigarh. The king Dhanyamanikya wanted this elephant, ordered the Kuki chieftain to send it to him as is his right. If viewed from the perspective of general ethics, it is an intrusion in the domain of others. But the objective and the focus stated in the introduction of the book that is to narrate the chivalry of Ray Kachag who fought for the sake of the kingdom of Tripura implicitly legitimizes and reinforces this order by the King as lawful and just. It is necessary to note here that the perspective that the writerillustrator adopts in this comic strip is essentially pro-royalty. The story narrates the efficiency of the Kuki community in battle as the victory on Thanasigarh was not possible for long eight months. At last the victory was possible because of Jamichalang whose idea of binding a rope in the highland with the help of his crocodile friend worked out. In fact the text deviates from the moral vs. immoral factors and introduces in roundabout way the politics, intelligence and principles and ethics of warfare ('rananiti' in Bengali) that are generally associated in royal battles. The concept of 'dharma' is thus problematised and complicated for the target readers of the text, and the text in many respects deviates from this concept by presenting every detail in comical manner usual for comic strip genre. Nothing is explicitly stated, only implied. But comic strip because of its pictorial quality exercises a lasting effect on the mind of the readers especially children. The concept of morality ethics or the judgment of good and evil is not acquired by the children so easily. The readers are mostly children who are not above the first two stages of moral development In the first stage, a child does not to do such things as are considered bad by the society or parents for the fear of hedonistic consequences and in the second, it is limited to loss- profit factor such as if you help me, I shall help you. Therefore comic strip succeeds in its stated aim by concealing any such morality judgment.

The inclusion of Jamichalang is definitely not only a figment of the writer-illustrator's imagination presented as fictional reality. The gaps and fissures in historical documentation is filled by mythology and folktale. Interestingly it does not hinder the narrative but adjusts itself to the requirements of the comic strip, children literature genre. The character of Jamichalang is clouded by obscurity as he is a character from folktale. He does not conform to any form of tradition, but is a blend of mythology and folktale and is also ahistorical as he denies age and time by resisting the prime determiner of canonical and conventional historical documentation viz. chronology. He had saved Kachag and introduced himself smilingly as "yes I am as apt in telling lie as strong. My name is Jamichalang. hee hee" (22, trans. mine). Kachag finds the name familiar and recollects that he has heard it in a fairytale told by his grandmother in his childhood (ibid). Later when Jamichalang departs, Kachag wonders, "strange person or is he really the superman ('atimanab' in Bengali) of the fairytale!'(26). Jamichalang helped Kachag twicein capturing Thanasigarh in 'Swet Hasti Parba' and in the battle with Husen Shah. It is interesting to note at the same time that the narration shows that Jamichalang captured the Kaman (canon) of Husen Shah and brought it to Kachag. This renders the objective stated in the introduction problematic. It can be interpreted that the fissure and gaps causing obscurity in historical narration is filled by myth and folktale, but at the expense of the importance of the central character. Jamichalang is indeed a strange character. He suddenly appears in the scene. He is a folk-tale element in the story and is a well-known character in fairy-tales. He does not wear shoes and in fact, is very much reluctant to do so, does not speak about his age or his origin. He remains obscure till the end and his character is a part of non-canonical history writing and new historiography. He refuses to go to Rangamatia (now Udaipur and the then capital of Tripura). A quarrel is hinted between him and the writers of Rajmala: "tomader rajmalar - lekhakra amake dekhe felle sarbanash. oder sange amar iye ache, he he he "(panel $2, \mathrm{p} 26)$. When Kachag insists on his going, he tells "e khetre kono aaposh noy. Ae:" meaning no compromise here (panel 4, p 26. trans. mine).

Again in 'Hushen Shah er Kaman', he tactfully avoids meeting King Dhanyamanikya when the king sends Kachag to fetch him (50). He is always with the common folk and never with royalty. He defies, resists and subverts being a part of canonical historiography. Rajmala is the record of royal history and therefore his 'maladjustment' with the writers of the text is hinted at since he defies time, ageing and also established literary and historical tradition of documentation. He is always ready with some pretext for his reluctance to wear shoes. When Kachag orders him to wear shoes as a part of the formality of soldiering (45), he tells "I'll. But in war it is more important to defeat the opposite army than to wear shoes" (46). He thus violates even the established tradition of wearing a 
soldier's uniform. Rajmala was written by royal historians and hence Jamichalang attempts to elude and delude all such definitive historical traces. He is a part of popular mythology and resists the form of writing that is monolithic, in the process revealing a power equation at play. He is a witness to history, but not a part of it. He denies any form of tradition defined by conventional history. In the target text there is a confusion as well as collaboration of myth and history, where myth tries to validate history, rendering history a problematic entity, like myth itself. It is not easy for the conscious or serious reader to deduce historical truth from other elements of history writing because of the narratology. Moreover, Senapati Ray Kachag as a text is non-canonical history writing aiming at the children as target readers. The comic strip genre with its pictorial and linguistic text clearly communicates the source culture both in time, space and humour as is expected from such type of text. The serious historical facts here do not distort the comic flavor. As a text it is as good a cultural production as a historical one. The inclusion of some comic dialogues or incidents is therefore likely. History and literature in such cases should not be treated as distinctly separate disciplines in order to privilege the former with respect to the latter or vice versa by implying in each a certain authority and absoluteness with respect to the other. Reality is always structured by the text, be it literary or historical, since no such exclusivity and purity of discipline is plausible. Senapati Ray Kachag is shown to be a loyal general of Tripura royalty. It is a blending of fact and fiction. The major question arising in analyzing such texts is the extent to which the imaginative fiction writing can go. Whether imagination is curbed by fiction or fiction is coloured by imagination cannot be definitely decided or deciphered from the target text. But some queries that arise on such an analysis are- To what extent and how far does ideology of the writer-illustrator get reflected in writing and recording historical facts? What do distortions in historical facts actually suggest? How does the past get represented in the text of the present? What is the difference in this case between visual text and typographical text? And all these issues in question stimulate the process of hierarchy formation, hegemonisation and appropriation inherent in the process of history writing.

\section{NOTES}

1. An important festival of the tribals of the state is held in the month of "April viz. "Baisakh" called "Garia-puja". Two deities "Kalia" and "Garia" is worshipped .The apex of a bamboo are bent in a particular fashion to assume the image of the deity. The image is then framed into a bamboo barrel and enthroned on a platform. Belief is held that the propitiation of the deity would make the people happy and prosperous. The Garia is a communal festival; sacrifice of cocks is done to mark the occasion. Dancing and rejoicing after performing puja is very essential.

The "Garia" dance is therefore very popular among the Tripuri's and the Reangs. Both men and women dressed in their best outfits ring and dance to the mellifluous tune of their exotic tribal music, which renders the whole atmosphere sublime and delightful .

2. Approximately $75 \mathrm{~km}$ from Agartala., the capital city of Tripura. It is famous for its rock carvings on the steep mountain wall on the bank of Gomati. There are beautiful huge carved images of Lord Shiva, Vishnu, Kartika, Mahishasur Mardini, Durga and other gods and goddesses. These images belong to 15th -16th centuries.

3.The slow lumbering giant lizards that most people go there to see. These endangered animals live on a small group of islands between Sumbawa and Flores in the Indonesian archipelago. The two biggest islands in the National Park are Komodo and Rinca. The nearest island on the regular tourist route is Bali and the nearest airport is on Flores. The Komodo Dragons live on Flores too.It is referred in the strip while linking the dragon brought by Jamichalang .It can be taken as an attempt to blend fact and fiction, fact and mythology.

4. Also known as pradip in Bengali . It works as comic strip iconography 'bulb' on the ground of its illuminating feature.

5.Present Udaipur, the northernmost village of Rangamatia was mentioned three times as an ancient kingdom in the Rajamala (a history of Tripura) by Kailash Chandra Singha. While the precise location was not described, the historical document notes it as situated east of the Kamalanka or Patikara kingdom. Rangamatia might have been the centre of this ancient kingdom. Rangamatia has been identified by some with Rohitagiri, the early kingdom and home of the Chandras of Bengal. 
6.The followers of Vaishnavism are referred to as Vaishnava(s) or Vaishnavites . Vaishnavism is a tradition of Hinduism, distinguished from other schools by its worship of Vishnu, or his associated Avatars such as Rama and Krishna, as the original and supreme God.Its beliefs and practices, especially the concepts of Bhakti and Bhakti Yoga, are based largely on the Upanishads, and associated with the Vedas and Puranic texts such as the Bhagavad Gita, and the Padma, Vishnu and Bhagavata Puranas.

7. The choric song sung by the Vaishnavas of Bengal . It is ususlly the chanting of the name of Lord Krishna accompanied by traditional musical instruments.

\section{Chattagram}

9. There is a reference in the text that it was created by the order of Hatian Khan when his soldiers were attacked or even killed by drinking the poisonous water poured on the river Gomati. But the text does not provide any authentic data as to where this historical lake is located at present Tripura. But as per the narrative it can be said that it was probably in somewhere between Rangamatia(Udaipur) and Amarpur.

10. An ethnic group that spread throughout the Northeastern region of India, Northwest Burma and Chittagong Hill Tracts in Bangladesh. In Northeast India they are present in all the states except Arunachal Pradesh. This dispersal across international borders is mainly attributed to the British colonial policy. It is said that Kukis had lived in Tripura even before the Tripuris came in to conquer the land. Those of the Kukis who had submitted to the Tripura 'Raja' came to be known as Halams.

11.Magan:Associated with Garia Festival of Tripura.The dancers sing a particular kind of song referred as magan and goes to gather offering from houses of locality. These songs are often accompanied by blessings ('bar' in Kokbarak). The use of Bengali language in such magan can be traced and it is said that it must have influenced the mingling and emergence of Bengali in Tripura and Kokborok language.

\section{References}

1. Conolly, Oliver. and Basshar Haydan 'The Case against Faction'.Philosophy and Literature. Philosophy and Literature 32.2(2008): 347-354.Abstract.Proejct Muse.Web.3 August 2011. <http://muse.jhu.edu/login?uri=/journals/philosophy- and -literature /vo32/32.2conolly html.>

2. Dasgupta, Alak. Senapati Ray Kachag . Agartala: Bhasa, 2003.Print.

3. Derrida, Jacques .Positions. trans. Alan Bass. London: Athlone. 1981. Print.

4. Dey. Ranjit. Tripurar Lokjiban and Loksanskriti .Pratham khanda .Kolkata: Nabajatak Prakashan. 1986.Print

5. Foucault, Michel : The Archaeology of Knowledge. London: Tavistock.1974.Print.

6. White, Hayden. Introduction .The Content of the Form: Narrative Discourse and Historical Representation. Baltimore: Johns Hopkins University .1987 .i-xv .Print. 